\title{
EFEK KATEKIN DAUN GAMBIR (Uncaria gambir Roxb) TERHADAP KADAR MALONDIALDEHID SERUM DAN EKSPRESI GEN SIRTUIN 1 PADA HIPOKAMPUS MENCIT BETINA MODEL PENUAAN
}

\author{
NOVRINA SITUMORANG, ${ }^{1}$ ZULHAM $^{2}$, LITA FERYAWATI ${ }^{3}$ \\ MAGISTER ILMU BIOMEDIK, FAKULTAS KEDOKTERAN \\ UNIVERSITAS SUMATERA UTARA \\ JL. DOKTER MANSYUR NO. 05, PADANG BULAN, MEDAN \\ e-mail: novrinasitumorang@ymail.com \\ DOI $10.35451 / \mathrm{jfm} . \mathrm{v} 3 \mathrm{i} 2.597$
}

\begin{abstract}
Aging is a physiological process that is indicated by progressive physiological disturbances, this results in impaired function and an increased risk of death. Accumulated damage to cell structures, especially in the nuclear and mitochondrial DNA, and accumulation of molecular waste inside and outside the cell, is the cause of aging. Free radicals are one of the elements that accelerate the aging process. Administration of $d$-galactose can induce overall aging of the organ system. Giving d-galactose for 6 consecutive weeks causes an increase in galactose in the body. Furthermore, aldose reductase converts galactose into galactitol, the accumulation of galactitol in cells causes changes in osmotic pressure, cell swelling, cell dysfunction, and aging. Sirtuin 1 (Sirt1) functions to regulate long-term survival of neurons through deacetylation and repression of p53, and FoxO mediated apoptosis. Giving antioxidants can prevent aging. Gambier plants contain many nutritious ingredients for health such as catechin. Catechins are compounds of the procyanidin oligomeric tannin group, have pharmacological effects similar to flavonoids, and are useful as antioxidants. The research was conducted experimentally using 28 female mice which were divided into 4 groups. Each group was injected with d-galactose $150 \mathrm{mg} / \mathrm{kgBW}$. Group $P 1$ received catechins of $100 \mathrm{mg} / \mathrm{kgBW}$, group $P 2$ received catechins of $200 \mathrm{mg} / \mathrm{kgBW}$ and group P3 received catechins of $400 \mathrm{mg} / \mathrm{kgBW}$. In this study, the results of serum MDA levels in all treatment groups were $p<0.05$ and the relative expression for Sirt1 was $p>0.05$. The conclusion of this research is that the catechins of gambier leaves can reduce serum MDA levels of female mice and cannot reduce the expression of Sirt1.
\end{abstract}

Keywords: Malondialdehyde, Sirtuin 1, Catechin. 


\section{PENDAHULUAN}

Penuaan merupakan proses fisiologis yang ditunjukkan dengan adanya gangguan fisiologi secara progresif, hal ini mengakibatkan terjadinya gangguan fungsi dan peningkatan resiko terjadinya kematian (López-otín et al., 2013).

Kerusakan ini menjadi faktor risiko utama terjadinya kanker, diabetes mellitus tipe II, gangguan kardiovaskular, dan penyakit-penyakit neurodegeneratif lainnya (López-otín et al., 2013; Rita R. Kalyani, Golden and Cefalu, 2017). Akumulasi kerusakan struktur sel terutama di DNA nukleus dan mitokondria, dan penumpukan sampah molekuler di dalam dan luar sel, menjadi penyebab penuaan (Ahmad, 2017).

Radikal bebas merupakan salah satu unsur yang mempercepat proses penuaan, bersifat sangat reaktif, dan cenderung bereaksi dengan molekulmolekul lain terutama lipid membran sel, protein, dan DNA. Perubahan struktur dan fungsi makromolekul tersebut menyebabkan kematian sel. Radikal bebas bersifat tidak stabil disebabkan adanya elektron dalam orbit terluarnya tidak berpasangan (Wahdaningsih et al.,2011)

Pemberian d-galaktosa dapat menginduksi terjadinya penuaan menyeluruh pada berbagai sistem organ (Ji et al., 2017). Pemberian d-galaktosa selama 6 minggu berturut-turut menyebabkan peningkatan galaktosa dalam tubuh (Ahangarpour et al., 2014). Selanjutnya, aldosa reduktase mengubah galaktosa menjadi galaktitol, galaktitol ini merupakan satu senyawa yang tidak dapat dimetabolisme oleh tubuh. Akumulasi galaktitol dalam sel menyebabkan terjadinya perubahan tekanan osmotik, pembengkakan sel, disfungsi sel, dan penuaan (Ye et al., 2014). Mekanisme ini mendorong pembuatan banyak hewan coba model penuaan menggunakan d-galaktosa (Sulistyoningrum, 2016). pemberian dgalaktosa menyebabkan terjadinya stress oksidatif pada berbagai jaringan melalui peningkatan produksi reactive oxygen species (ROS) dan advanced glycation endproduct seperti layaknya terjadi pada penuaan alamiah (Mohammadi et al., 2018).

Sirtuin 1(Sirt1) berfungsi untuk mengatur kelangsungan hidup jangka panjang neuron melalui deasetilasi dan represi p53,dan apoptosis yang diperantarai oleh FoxO (Nakae et al., 2006).Selain itu, Sirt1 juga menjaga integritas dan biosintesis neuron secara tidak langsung melalui aktivitas NAD (Guarente, 2013). Sirt1 juga berperan sebagai neuroprotektor pada proses penuaan yang normal dan gangguan neurodegeneratif dengan cara mencegah degenerasi aksonal, toksisitas polyglutamine dan toksisitas mikroglia. Peningkatan ekspresi Sirt1 di neokorteks, bersamaan dengan pengurangan karbohidrat, dapat mencegah neuropati amiloidosasi (Shoba et al., 2009).

Pemberian antioksidan dapat mencegah terjadinya penuaan. Flavonoid banyak terdapat pada jaringan tanaman, sereal, sayur dan buah-buahan. Diet yang kaya akan buah dan sayur mengurangi risiko penyakit dan menunda penuaan (Kaira, 2010). Tanaman gambir mengandung banyak bahan berkhasiat bagi kesehatan seperti katekin (Zhalimi, 2006). Katekin merupakan senyawa golongan tanin oligomeric procyanidin, berefek farmakologis mirip dengan flavonoid, dan berguna sebagai antioksidan (Kristina, 2019). Oleh karenanya efek katekin daun gambir terhadap kadar MDA serum dan ekspresi Sirt1 hipokampus mencit model penuaan perlu dikaji. 


\section{METODE}

Jenis penelitian ini adalah eksperimental in vivo dengan desain penelitian post test -only control group (Budiarto, 2001).

Penelitian dilaksanakan di Laboratorium Farmakologi, Fakultas Kedokteran Sumatera Utara (FK USU) untuk pemeliharaan mencit model penuaan dan perlakuan terhadap hewan model. Penelitian dilanjutkan di laboratorium terpadu FK USU untuk pemeriksaan kadar MDA serum dan pemeriksaan ekspresi Sirt1 hipokampus. Penelitian dilaksanakan pada bulan April 2019 selama 6 minggu.

Populasi penelitian adalah mencit betina yang berumur 2,5-3 bulan dan berat badan $20-35 \mathrm{~g}$.

Penetapan besar sampel menggunakan rumus Federer (1966), ditetapkan jumlah mencit yang digunakan dalam penelitian ini adalah 28 ekor mencit yang dibagi kedalam 4 kelompok, yaitu:

PO adalah kelompok kontrol;

P1 adalah kelompok mencit yang diberikan katekin $100 \mathrm{mg} / \mathrm{kgBB}$;

P2 adalah kelompok mencit yang diberikan katekin 200 mg/kgBB;

P3 adalah kelompok mencit yang diberikan katekin 400 mg/kgBB.

Kriteria inklusi dalam penelitian ini adalah dalam keadaan tidak atau belum pernah hamil, berasal dari tempat pembiakan yang sama, dipelihara pada tempat dan waktu yang sama, belum pernah digunakan sebagai bahan penelitian. Sedangkan Kriteria eksklusinya adalah semua mencit betina yang tampak sakit ditentukan dengan gerak terbatas, bulu terlihat kusam atau terdapat luka/bekas gigitan.

Kadar katekin diukur dengan menggunakan timbangan gelas ukur.
Kadar MDA diukur dengan menggunakan alat spektrofotometer. Ekspresi sirt1 diperiksa dengan menggunakan metode Real Time PCREkspresi $\beta$ aktin. Persetujuan etik untuk prosedur penelitian dan penanganan hewan model didapat dari Komite Etik Penelitian FMIPA USU Medan.

\section{HASIL}

\section{Pengaruh Pemberian Katekin Daun Gambir terhadap Kadar MDA Serum}

Kadar MDA serum pada kelompok PO tidak berdistribusi normal $(\mathrm{p}<0.05)$ namun kelompok $\mathrm{P} 1, \mathrm{P} 2$, dan P3 memiliki distribusi data yang normal (Tabel 3.1). Selanjutnya, perbedaan kadar MDA serum pada tiap kelompok perlakuan diuji menggunakan uji Kruskal Wallis (Tabel 3.2). Tabel 3.3 menunjukkan perbandingan kadar MDA serum pada semua kelompok adalah berbeda bermakna $(p<0,05)$. Analisis dilanjutkan dengan uji Mann Whitney untuk mengetahui kelompok mana yang saling berbeda. Tabel 3.3 menunjukkan bahwa kadar MDA serum berbeda bermakna $(p<0,05)$ antara kelompok PO dengan P2 dan antara kelompok P0 dengan P3

Tabel 3.1 Hasil Uji Normalitas Data Kadar MDA Serum Hewan Coba

\begin{tabular}{ll}
\hline \multicolumn{1}{c}{ Kelompok } & $\mathrm{p}$ \\
\hline P0 & 0,031 \\
P1 & 0,132 \\
P2 & 0,308 \\
P3 & 0,751 \\
\hline
\end{tabular}


Tabel 3.2 Nilai mean, standar deviasi serta perbedaan kadar MDA serum

\begin{tabular}{ccc}
\hline $\begin{array}{c}\text { Kelompo } \\
\text { k }\end{array}$ & $X \pm S D$ & $P$ \\
\hline P0 & $42,30 \pm 20,4$ & \\
& 7 & \\
P1 & $25,07 \pm 25,6$ & 0,02 \\
1 & 0 \\
P2 & $11,20 \pm 3,90$ & \\
P3 & $11,79 \pm 2,19$ & \\
\hline
\end{tabular}

Tabel 3.3 Uji beda rerata kadar MDA serum kelompok perlakuan

\begin{tabular}{ccc}
\hline Kelompok & Versus & $\mathrm{P}$ \\
\hline P0 & P1 & 0,171 \\
& P2 & $0,010^{*}$ \\
& P3 & $0,010^{*}$ \\
P1 & P2 & 0,486 \\
& P3 & 0,343 \\
P2 & P3 & 0,686 \\
\hline
\end{tabular}

${ }^{*}$ Signifikan $(p<0,05)$

\section{Pengaruh Pemberian Katekin Daun gambir Terhadap Ekspresi Relatif Sirt1 Hipokampus Mencit}

Tabel 3.4 menunjukkan bahwa $\Delta \mathrm{C}_{\mathrm{t}}$ pada tiap kelompok tidak berbeda bermakna $(p>0,05)$

Tabel 3.4 Nilai mean, standar deviasi serta perbedaan $\Delta C_{t}$

\begin{tabular}{clc}
\hline Kelompok & $X \pm S D$ & $p$ \\
\hline P0 & $8,85 \pm 1,48$ & \\
P1 & $8,89 \pm 1,17$ & 0,865 \\
P2 & $9,28 \pm 1,58$ & \\
P3 & $9,51 \pm 1,51$ & \\
\hline
\end{tabular}

Gambar 3.1 menunjukkan bahwa pemberian ekstrak daun gambir selama 6 mingggu berturut-turut menurunkan ekspresi relative sirt1, dimana kelompok P1 0,49, kelompok P2 0,74, kelompok P3 0,49 . Penurunan terbesar terjadi pada kelompok P3. Namun, kelompok P2 menunjukkan penurunan yang paling sedikit berbanding P1 dan P3.

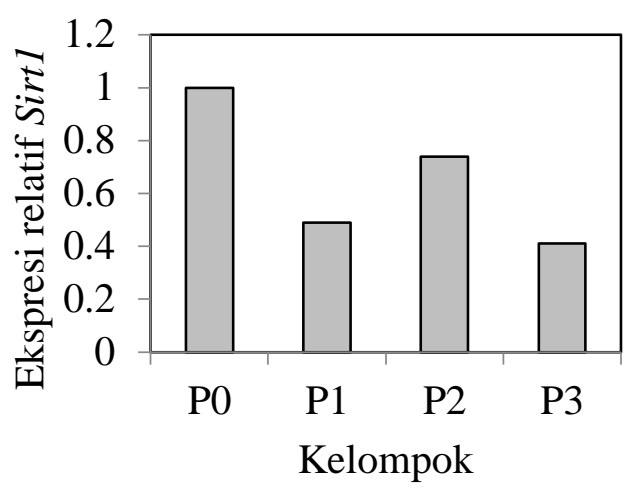

Gambar 3.1 Ekspresi relatif Sirt1 hipokampus mencit betina model penuaan.

\section{Pembahasan}

\section{Pengaruh Pemberian Katekin Daun Gambir terhadap Kadar MDA Serum}

Kadar MDA serum pada kelompok PO lebih tinggi sedikit dibandingkan dengan kadar MDA serum pada kelompok $\mathrm{P} 1$, sedangkan pada kelompok P2 kadar MDA lebih rendah dibandingkan dengan kelompok PO. Kelompok P3 menunjukkan nilai MDA yang lebih tinggi dibandingkan dengan kelompok P2 (Tabel 3.3). Dalam hal ini kemungkinan aktivitas dari antioksidan berubah menjadi prooksidan sehingga menghasilkan pembentukan radikal $\mathrm{O}_{2}{ }^{-}$ dan ROS lainnya (Nagao et al., 2005)

Proses peroksidasi lipid dimulai dari ion $\mathrm{H}^{+}$pada rantai samping PUFA penyusun membran sel membentuk radikal karbon. Radikal karbon tersebut teroksidasi dan membentuk radikal peroksil. Kadar MDA yang tinggi menunjukkan terjadinya oksidasi atau rusaknya membran sel akibat radikal bebas.

Katekin telah terbukti efisien sebagai pengikat radikal bebas secara in vitro. Kemampuan katekin sebagai pengikat radikal bebas sebagiannya terkait dengan potensi reduksi satu elektronnya yang merupakan ukuran suatu reaktivitas antioksidan sebagai hidrogen. Semakin rendah potensi 
reduksi menunjukkan energi yang diperlukan untuk mendonorkan suatu elektron juga semakin rendah.

Selain katekin daun gambir yang dapat berperan sebagai antioksidan eksogen, banyak antioksidan eksogen lain yang dapat mengatasi penuaan. Zhao et al. (2018) menyebutkan bahwa asam linolenat dan asam linoleat yang terkandung didalam minyak walnut, antosianin dan prosianidin yang terkandung dalam ekstrak kulit anggur juga memiliki efek antioksidan dan antiinflamasi yang kuat sehingga dapat juga digunakan sebagai antiaging. Ketiganya secara efektif mengurangi radikal bebas dan meningkatkan kapasitas oksidan yang dibuktikan dengan penurunan kadar MDA serum dan hati pada tikus model penuaan. Selain itu, Nam et al. (2019) menyebutkan bahwa vitamin $C$ mempunyai efek antioksidan dan mencegah terjadinya penurunan ekspresi sirtuin 1 pada tikus model penuaan. Penelitian lain menyebutkan bahwa Vitamin E juga memiliki efek antioksidan dan mencegah produksi ROS sehingga vitamin $E$ dapat digunakan sebagai antioksidan eksogen (Rizvi et al., 2014). Mueller dan Boehm (2011) juga menyebutkan bahwa $\beta$ caroten memiliki efek antioksidan yang kuat karena dapat mengatasi ROS.

\section{Pengaruh Pemberian Katekin Daun Gambir terhadap Ekspresi Relatif Sirt1 Hipokampus Mencit}

Pada penelitian ini ekspresi Sirt1 tidak mengalami peningkatan pada semua kelompok perlakuan. Salminen et al. (2013) menyatakan bahwa peningkatan ROS dapat menghambat Sirt1. Pemberian katekin melalui sonde menyebabkan katekin dimetabolisme menjadi konjugat glukuronida katekin dan 3'-O-metil katekin (3'OMC). Katekin tidak dijumpai dalam plasma vena mesenterika sehingga menunjukkan bahwa seluruh atau hampir seluruh katekin oral telah dimetabolisme dan diserap dalam bentuk bukan katekin (Donovan et al., 2001). Keberadaan 3'OMC dalam parenkima otak hingga kini belum diteliti. Hal ini menimbulkan dugaan bahwa 3'OMC dan metabolit katekin lainnya tidak mampu menembus sawar darah otak. Selanjutnya, peningkatan ROS hipokampus yang diinduksi oleh $d$ galaktosa, tidak dapat dipengaruhi oleh 3'OMC dan metabolit katekin lainnya.

\section{KESIMPULAN}

1. Katekin daun gambir (Uncaria gambir Roxb) menyebabkan terjadinya penurunan kadar MDA serum mencit model penuaan diinduksi oleh d-galaktosa.

2. Dosis optimal katekin daun gambir (Uncaria gambir Roxb) untuk menurunkan kadar MDA serum adalah $200 \mathrm{mg} / \mathrm{kgBB}$.

3. Katekin daun gambir (Uncaria gambir Roxb) menurunkan ekspresi relatif Sirt1 hipokampus mencit model penuaan diinduksi oleh d-galaktosa.

\section{DAFTAR PUSTAKA}

Ahangarpour, A. et al. (2014) 'Effect of Boswellia serrata supplementation on blood lipid, hepatic enzymes and fructosamine levels in type2 diabetic patients', journal of diabetes and metabolic disorder, 8, pp. $1-5$.

Ahmad, D. (2017) 'Penuaan Kulit: Patofisiologi dan Manifestasi Klinis', jurnal berkala ilmu kesehatan kulit dan kelamin, 30, pp. 208-215.

Bernatoniene, J. and Kopustinskiene, D. M. (2018) 'The Role of Catechins in Cellular Responses to Oxidative Stress', Molecules, 23(4), pp. 111.

Budiarto (2001) Biostatistika untuk kedokteran dan kesehatan masyarakat. EGC.

Chung, S. et al. (2011) 'Regulation of 
SIRT1 in cellular functions: role of polyphenols', Arch Biochem Biophys, 501(1), pp. 79-90.

Donovan, J. L. et al. (2001) 'Catechin Is Metabolized by Both the Small Intestine and Liver of Rats', American society for nutritional sciences, (January), pp. 17531757.

Fadlurrahman, A. R. (2018) 'Penentuan Kadar Malondialdehid (MDA) pada Saliva Wanita Perokok Usia 26 35', Majalah Kesehatan PharmaMedika, pp. 78-84.

Guarente, L. (2013) 'Calorie restriction and sirtuins revisited', Genes and Development, 27(19), pp. 20722085.

Ji, M. et al. (2017) 'Comparison of naturally aging and D-galactose induced aging model in beagle dogs', Experimental and Therapeutic Medicine, 14(6), pp. 5881-5888.

Juniaty, T. (2013) 'Kandungan Senyawa Kimia pada Daun Teh (Camellia sinensis)', Warta Penelitian dan Pengembangan Tanaman Industri, pp. 12-16. Kaira, K. (2010) 'Menangkal Radikal Bebas dengan Antioksidan', Saintek, 2, pp. 183-187.

Kristina, N., Lestari, J. and Fauza, M. (2019) 'Keragaman morfologi dan kadar katekin tanaman gambir berdaun merah yang tersebar pada berbagai ketinggian tempat di Sumatera Barat', in Seminar Nasional Masyarakat Biodiversitas Indonesia, pp. 43-48.

López-otín, C. et al. (2013) 'The Hallmarks of Aging', Cell, 153(6), pp. 1194-1217.

Mohammadi, E. et al. (2018) 'Protective effect of crocin against d-galactose-induced aging in mice', 8(1), pp. 14-23.

Mueller, L. and Boehm, V. (2011) 'Antioxidant Activity of $\beta$-Carotene Compounds in Different in Vitro Assays', molecules, 16, pp. 10551069.

Nagao, T. et al. (2005) 'Ingestion of a tea rich in catechins leads to a reduction in body fat', (1), pp. 122-129.
Nam, S. M. et al. (2019) 'Ascorbic Acid Mitigates D-galactose-Induced Brain', nutrient, 11, pp. 1-17.

Pervin, M. et al. (2019) 'Function of Green Tea Catechins in the Brain : Epigallocatechin Gallate and its Metabolites', International journal of Molecular Sciences, (Figure 1), pp. 1-12.

Putu Moda Arsana, Laksmi Sasiarini, B. E. N. (2019) 'Pengaruh Suplementasi Ekstrak Teh Hijau terhadap Kadar Malondialdehid Plasma pada Individu dengan Controlled Trials', Jurnal Penyakit Dalam Indonesia, 6(1), pp. 23-30.

Rita R. Kalyani, Golden, S. H. and Cefalu, W. T. (2017) 'Diabetes and Aging: Unique Considerations and Goals of Care', Diabetes Care, 40(4), pp. 440-443.

Rizvi, S. et al. (2014) 'The Role of Vitamin E in Human Health and Some Diseases', Sultan qaboos university med jounal, 14(May), pp. 157-165.

Salminen, A., Kaarniranta, K. and Kauppinen, A. (2013) 'Crosstalk between Oxidative Stress and SIRT1 : Impact on the Aging Process', pp. 3834-3859.

Shoba, B. et al. (2009) 'Function of sirtuins in biological tissues', Anatomical Record, 292(4), pp. 536-543.

Shwe, T. et al. (2018) 'Role of Dgalactose-induced brain aging and its potential used for therapeutic interventions', Experimental Gerontology, 101, pp. 13-36.

Sidorova-darmos, E., Sommer, R. and Eubanks, J. H. (2018) 'The Role of SIRT3 in the Brain Under Physiological and Pathological Conditions', 12(July), pp. 1-16.

Singh, C. K. et al. (2017) 'The Role of Sirtuins in Antioxidant and Redox Signaling', pp. 1-54.

Singh, C. K. et al. (2018) 'The Role of Sirtuins in Antioxidant and Redox Signaling', Therapeutic, 28(8), pp. 643-661.

Siswonoto, S. (2008) Hubungan Kadar Malondialdehid Plasma Dengan Keluaran Klinis Stroke Iskemik Akut. Universitas Diponegoro. 
Sulistyoningrum, E. and Article, R. (2016) 'Jurnal Kedokteran dan Kesehatan Indonesia D-galactoseinduced animal model of male reproductive aging', pp. 19-28.

Wahdaningsih, S., Setyowati, E. P. and Subagus, W. (2011) 'Aktivitas Penangkap Radikal Bebas Dari Batang Pakis ( Alsophila glauca J . Sm )', Majalah Obat Tradisonal, 16(3), pp. 156-160.

Ye, Y. et al. (2014) 'In vivo antioxidant and anti-skin-aging activities of ethyl acetate extraction from idesia polycarpa defatted fruit residue in aging mice induced by $D$ galactose', Evidence-based Complementary and Alternative Medicine, 185716, pp. 1-12.

Zhao, H. et al. (2018) 'Antioxidant effects of compound walnut oil capsule in mice aging model induced by D-galactose', 1, pp. 110. 